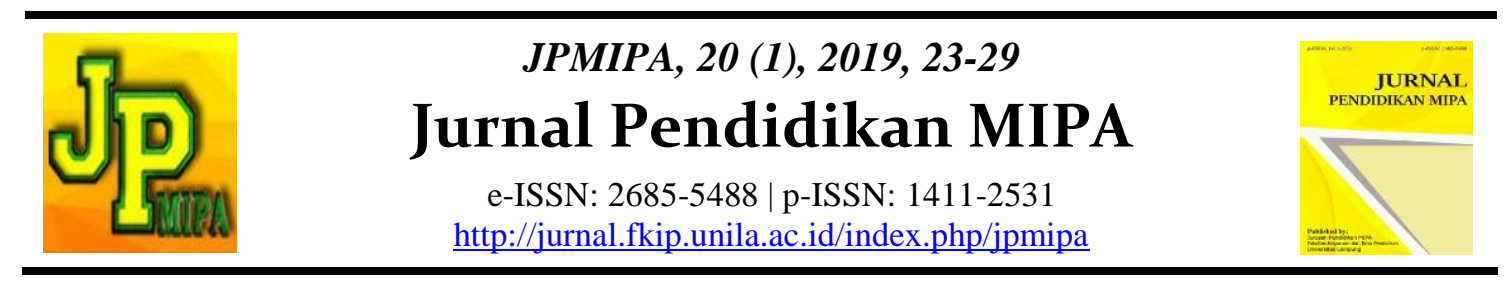

\title{
Development of Performance Assessment Instrument for Electrolyte and Non Electrolyte Solutions
}

\author{
Besta Rosita Sahara, Nina Kadaritna, Lisa Tania
}

Department of Chemical Education, University of Lampung, Indonesia

\begin{abstract}
This study was aimed to develop the performance assesment instrument on the practice of electrolyte and non-electrolyte solution, to describe the characteristics in terms of legibility, construction, implementation of product, and to describe the teachers responses on the performance of developed. The design of this research was Research and Development (R\&D). The result of expert validation toward assessment instrument showed the level readable realibility, construction, and implementation of the performance assesment instrument equal to $91,11 \%, 84 \%$, and $100 \%$; respectively. The teachers gave very good responses to the legibility content, construction, and implementation of the performance assesment instrument with percentage were $96,67 \%, 96 \%$, and $96,67 \%$ respectively. The conclusion obtained from this research is the performance of developed were excellent.
\end{abstract}

Keywords: assessment performance instrument on experiment, electrolyte solution development.

Abstrak: Penelitian ini bertujuan untuk mengembangkan instrumen asesmen kinerja praktikum larutan elektrolit dan non elektrolit, mendeskripsikan karakteristiknya dari segi keterbacaan, konstruksi dan keterpakaian produk, serta mendeskripsikan tanggapan guru kimia terhadap instrumen yang dikembangkan. Desain penelitian yang digunakan adalah Research and Development $(R \& D)$. Hasil validasi ahli terhadap instrumen asesmen kinerja yang dikembangkan menunjukkan aspek keterbacaan 91,11\%; aspek konstruksi 84\%; dan aspek keterpa $\neg$ kaian $100 \%$; yang termasuk dalam kategori sangat tinggi. Guru juga telah memberikan tanggapan dengan sangat baik terhadap aspek keterbacaan, konstruksi dan keterpakaian produk dengan persentase masing-masing 96,67\%, 96\%, dan 96,67\%. Kesimpulan yang diperoleh pada penelitian ini yaitu instrumen asesmen kinerja praktikum yang dikembang $\neg$ kan memiliki kriteria sangat baik.

Kata kunci: instrumen asesmen kinerja praktikum, larutan elektrolit, pengembangan.

Sahara et al.

Email: bestarosita141@gmail.com
DOI: http://dx.doi.org/10.23960/jpmipa/v20i1.pp23-29

Received: 07 May 2019

Accepted: 28 June 2019 


\section{- INTRODUCTION}

The assessment of learning outcomes by teachers is carried out to monitor the process, progress of learning, and continuous improvement of student learning outcomes. Assessment of learning outcomes by the teacher has a role, among others, namely to help students know the achievements of learning (learning outcomes), as well as teachers and students can obtain information about the weaknesses and strengths of learning and learning (Permendikbud No 104, 2014). Learning is said to be effective, efficient and productive when accompanied by good assessment (Stiggins in Sudrajat, A., Permanasari A., Zainul A., and Buchari, 2011).

Assessment plays a very important role, because the assessment is expected to provide feedback about the material students have learned, the effectiveness of the learning process and student learning outcomes (Kusaeri and Suprananto, 2012). The scope of the assessment includes the attitudes, knowledge and skills competencies carried out in a balanced manner so that it can be used to determine the relative position of each student towards the prescribed standards (Anonim, 2013a). Assessment or assessment is a process of getting information about what students have learned and how successful the students are in learning it (Abidin, 2014).

Assessment carried out on students can be used as evidence that should be considered in the implementation of learning evaluation, because it is not only assessing students, assessment is also used in assessing the teaching system (Hamalik, 2001). Assessment of learning outcomes in practical skills competencies can use performance assessment (Anonim, 2014a). Performance assessment is considered as one form of assessment that sees student competence not only in terms of cognitive, but also viewed from the psychomotor perspective of students (Ardli, I., Abdullah, A.G., Mujdalipah, S., and Ana, 2012). Performance assessment is important, because it can motivate students to demonstrate a process that can be observed directly. Therefore, the performance assessment is very suitable to assess the achievement of competencies that require students to perform certain tasks such as practicum (Wulan, 2013).

In practice, performance assessments are carried out using assessment instruments or performance assessment instruments. An assessment instrument is a tool used to assess students in achieving learning (Anonymous, 2014a). Performance assessment instruments used in measuring students' abilities in an indicator must be equipped with a rubric (Susila, 2012). The rubric serves as the assessment standard for clearly identifying student performance in the form of a score guide for the expected criteria (Wulan, 2013). By referring to this rubric, student performance in practical activities can be assessed by the teacher. One subject that is closely related to practical activities is a chemical subject. Practical activities in chemistry learning are very important (Abrahams I., Reiss, M.J., and Sharpe, R.M., 2013). This is because practicum activities can help students build chemical concepts. Therefore, every learning activity related to practical activities requires a performance assessment to assess this. One example of the basic competency in chemistry learning is Basic Competence (KD) 4.8 designing, doing, and concluding and presenting the results of experiments to determine the nature of electrolyte solutions and non-electrolyte solutions (Anonim, 2014b). To reach the $\mathrm{KD}$, students are trained to design and experiment with electrolyte and non-electrolyte solutions, then an assessment of the student's lab performance is carried out.

The fact is that the use of performance assessments in schools is still very limited (Wulan, 2007). This fact corresponds to the research conducted by Karviyani (2015) on the development of practicum performance assessments on acid-base material, from the 
results of the study explained that some teachers do not provide practicum performance assessments and there are some teachers who have done practicum assessments but did not make assessment rubric. The teacher finds it difficult to make a performance assessment instrument along with the rubric and indicators, this is because the teacher does not understand the performance assessment instrument and the teacher never makes a performance assessment instrument (Oktriawan, 2015). In addition, performance assessment procedures offered by assessment experts are too complex, namely the performance components that are overvalued and not appropriate to assess the performance of students in large numbers and scoring guidelines used are unclear, making it difficult to understand and difficult to implement on daily learning activities (Susila, 2012; Wulan, 2008).

\section{- METHOD}

Research and development of practicum performance assessment instruments on electrolyte and non-electrolyte solution material consisted of several stages according to Borg and Gall in Sukmadinata (2011), but this study was only carried out until the revision phase of the trial results. This is due to limited time and lack of research expertise to carry out the next stage. This stage aims to collect data on existing conditions as a comparison material for developed products. At this stage there are three Public High Schools in Lampung Province and one private high school in Bandar Lampung. Instructional methods are questionnaires. The questionnaire was distributed to 40 class XI students and four chemistry teachers in the four high schools who had obtained electrolyte and non-electrolyte solution material.

The data produced is classified and the percentage of answers is calculated. Calculation of the percentage of income, aims to see the percentage of each answer to the question so that the data obtained can be analyzed. At this stage, the draft product of practicum performance assessment instruments was designed based on the results of library studies and field studies, that most teachers did not understand the practical performance assessment instruments and the complexity of assessment procedures so that they were difficult to apply. teacher. Therefore, design performance assessment equipment that is efficient, practical, and easy to learn so that it is easy to use by the teacher. After the product design is complete, the performance assessment instruments are arranged according to the product design that has been made. The product is ready to be validated by an expert validator, namely a lecturer at the Lam $\neg$ pung University Chemistry Management. Verification was made on aspects of product use, construction aspects and reading aspects of performance assessment instruments in electrolyte and non electrolyte solution labs. After the validation is complete, the data from the validation results are recorded and tabulated.

At this stage, the researcher conducted an implementation test for the 2017 Chemical Education students. This stage can be used to determine the suitability of the task with the rubric that has been made. If there is a performance that does not appear, it needs to be changed according to the performance that appears in the implementation test. Next do the trial limit. The purpose of this test is to find out the teacher's response to aspects of reading, construction, and product use of the practicum performance assessment instrument. This limited trial was carried out by showing assessment instruments for the performance of electrolyte and non-electrolyte solution practices and asking two chemistry teachers in class XI in one of the Public High Schools in Bandarlampung to respond to products that had been developed by filling out 
questionnaires that had been provided. After that the results of the percentage answer $\neg$ questionnaire are interpreted based on the interpretation of Arikunto (2008).

\section{- RESULT AND DISCUSSION}

The results of the curriculum analysis are KI-KD-Indicators. The results of the assessment of assessment literature and research results related to the assessment of practicum performance are ways of preparing assessments and knowing the criteria for good assessment instruments, as well as references in developing laboratory performance assessment instruments. The results of the field study found several facts about teacher responses found in Figure 1. Practical performance assessment used by teachers, $25 \%$ of teachers did not always carry out practical activities on chemical learning processes. As many as $50 \%$ of the teachers did not conduct electrolyte and nonelectrolyte solution practicum activities so that they were replaced with learning media in the form of power points, video de- monstrations and illustrations in the form of books. Furthermore, $50 \%$ of teachers assess the ability of student performance in conducting practical activities. As many as $75 \%$ of teachers do not understand the performance assessment. Teachers who have never made a performance assessment instrument to measure student performance abilities are as much as 75\% and all teachers answer that it is necessary to develop assessment instruments.

The students' responses to the questionnaire are shown in Figure 1. Based on these images, $85 \%$ of the students answered that they always practiced the chemistry learning process. As many as $50 \%$ of students have practicum guides and $50 \%$ of students answer that the teacher explains the practicum procedure and explains how to use the instrument before practicing on electrolyte and non-electrolyte solution material. As many as $90 \%$ of students answered it was important to do practical activities on electrolyte and non-electrolyte solution material because it would have good consequences for them, namely to be careful and careful in practicum be careful in using laboratory tools and materials and more enthusiasm in practicum so that the resulting value is maximized. The product planning will be developed, which consists of the initial part (front cover, inner cover, introduction and table of contents), content section (practicum guide, assessment method, task and performance rubric) and the final part (bibliography and back cover) .

In product development there are revised product components, while the front cover display before and after revision is presented in Figure 3. The cover of the title sentence is neatly arranged, the image is replaced because it is unclear and the practicum in the picture is the teacher. In the preface there are deficiencies, namely the use of languages that do not follow the rules of EYD, preface before and after revisions are presented in Figure 4. The next section is revised task and the performance rubric. Performance tasks and rubrics are made of two types, tasks and detailed performance and task rubrics and performance rubrics based on new scenarios. Task and performance rubrics in detail are all skills at the time the lab is observed, this is so that the educator knows all the performance that is assessed according to the stages in the experimental procedure.

If the performance assessment is compiled based on all stages of performance or stages of the experimental work step, then the performance assessment will be very detailed and complex (Wulan, 2008). If these skills are applied to the daily practice, the teacher will be difficult and overwhelmed in assessing students' skills, because it is not in accordance with the large number of students. Therefore the assessment needs to be 
revised to be simpler, the performance assessment is simply a performance assessment based on a new assessment scenario (Wulan, 2008). The performance taken is only representative performance from all stages of the skills assessed.
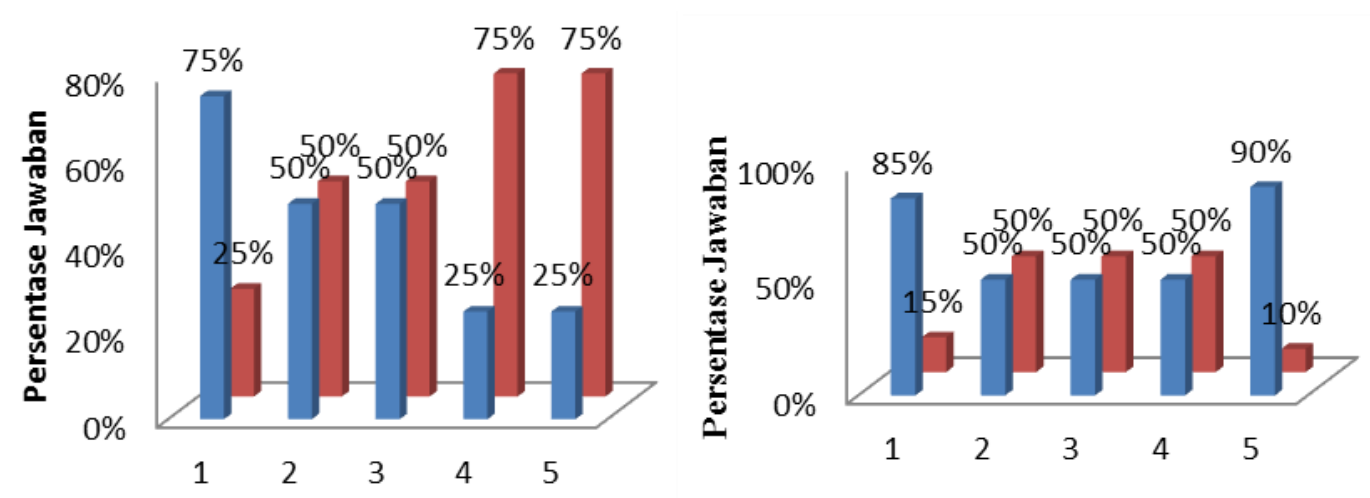

Figure 1. Percentage of answers to questionnaire filling by the teacher (left) and students (right)

In addition to compiling products, research instruments were also prepared to assess the products developed. The assessment instrument consisted of expert validation instruments, teacher response instruments, and the implementation observation sheet of performance assessment. Expert validation instruments and teacher response instruments include aspects of readability, construction and use of products used to assess the product being developed. while the observation sheet is used to test the implementation of the product performance assessment instruments developed

Based on the readability aspect, according to the validator of the performance assessment instrument in general it is in accordance with the rules of EYD writing, but there are still writing sentences that do not follow the rules of EYD. Writing does not use words that can give rise to multiple meanings and the use of language is easy to understand. The results of expert validation showed that the readability aspect obtained a percentage of $91.11 \%$. The results of this percentage indicate that the practicum performance assessment instruments developed are included in very high criteria. In the aspect of construction, the validator stated that the assessment instrument for the performance of electrolyte and non-electrolyte solution practicum developed according to the task with the experimental procedure, the aspect was considered an important aspect in the experiment and was in line with the performance assessment instrument with the task. The results of expert validation for construction aspects yield percentages of $84 \%$ which indicates that the development of practicum performance assessment instruments has a very high category.

In the aspect of product use, according to the validator the performance assessment instrument developed has been very simple and easy for the teacher to be able to assess the performance of all students in the same time and the percentage of the validator's assessment is $100 \%$. The percentage of product utilization aspects is $100 \%$ with a very high interpretation of scores. The average percentage of the questionnaire aspects of reading, product use, and construction are included in the high category so that assessment instruments for the performance of development outcomes have been compiled and have met these three aspects and can used for initial field trials. After the assessment instrument for the performance of electrolyte and non-electrolyte solutions 
developed was completed by the Valiator, the next step was to carry out a feasibility test on the practicum performance assessment instrument on electrolyte and non-electrolyte solution materials. The initial product of the practicum performance assessment instrument before being tested to school, was tested beforehand on the 2017 students of Chemical Education. Experiments were carried out in the chemistry learning laboratory FKIP Unila with 10 students. Based on the results of the trial results, this performance assessment instrument has no revisions.

After being tested on students, implementation tests were conducted on 10 students in one of the Public High Schools in Bandar Lampung. This study uses product validity, namely the use of practical performance assessment instruments for use by teachers in schools. If the developed instruments are easy to use, then the performance assessment instruments are considered valid. Based on the results of the implementation test with students, the performance assessment instrument has no revisions. Furthermore, a limited trial is carried out, aiming to find out the teacher's response to the product that has been developed. The aspects assessed are readability, construction and product wear. The assessment apparatus of the electrolyte and non-electrolyte solutions were tested in SMA 17 Bandar Lampung. The respondents in the trial were two chemistry teachers. Fill in the statement of the results of the validation aspects of readability about the use of language that is in accordance with standard of indonesian language, a language that is easy to understand and does not cause multiple meanings. Based on the assessment of the percentage teacher is $96.67 \%$ with a very high category, it can be concluded that the readability aspect of the development of performance assessment instruments is good.

In the aspect of construction, according to the teacher it is appropriate between the task and the experimental procedure, aspects that are considered to be important aspects and rubrics of the performance assessment apparatus are in accordance with the task. The construction aspect of the development of the practical performance assessment instrument has been good so there is no revision. These results are also reinforced by data through a total calculation of $96 \%$ so that it falls into the very high category. In the aspect of product use, instruments that have been produced are simple, easy to carry out assessments during practical work and cost-effective. The average percentage of $96.67 \%$ indicates that the aspect of the use of the product of the performance assessment instrument is included in the high category. Overall, the results of the assessment on aspects of readability, construction and product use by the teacher indicate that the development of assessment instruments for the performance of electrolyte and nonelectrolyte solutions is good so that it can be used as a reference for teachers to carry out practical assessment. Based on the development that has been done, it can be known that the assessment instrument performance of electrolyte and non-electrolyte solution labs has characteristics including being able to be applied in the implementation of school, efficient, and easy to use by the teacher. The supporting factors are cooperation between teachers and students with good researchers. There were no significant obstacles during development.

\section{- CONCLUSION}

Based on the results of the research and discussion it was concluded that the performance assessment instruments of the development results had characteristics that could be applied in their implementation at school, efficiently, and were easily used by the teacher. The teacher responded very well to the performance assessment instruments 
of practicum which were developed with the results of the percentage of readability aspects of $96.67 \%$, construction aspects of $96 \%$ and aspects of product use $96.67 \%$ in the very high category. Performance assessment instruments on electrolyte and nonelectrolyte solution practicum results from development are supported by a simple and practical assessment and task rubric, so that it is easy to use by teachers in evaluating practical performance. There were no significant obstacles during the development of practicum performance assessment instruments on electrolyte and non-electrolyte solution materials.

\section{- REFERENCES}

Abidin, Y. (2014). Desain Sistem Pembelajaran dalam Konteks Kurikulum 2013. Refika Aditama. Bandung.

Abrahams, I., Reiss, M.J., \& Sharpe, R.M. (2013). The Assessment of Practical Work in School Science. Studies in Science Education. 49(2), 209-251.

Ardli, I., Abdullah, A.G., Mujdalipah, S., \& Ana. 2012. Perangkat Penilaian Kinerja untuk Pembelajaran Teknik Pemeliharaan Ikan. INVOTEC, 8(2), 147-166.

Arikunto, S. (2008). Dasar-Dasar Evaluasi Pendidikan. Bumi Aksara. Jakarta.

Hamalik, O. (2001). Proses Belajar Mengajar. PT Bumi Aksara. Jakarta.

Karviyani, S., Rosilawati, I., \& Efkar, T. (2015). Pengembangan Instrumen Asesmen Kinerja Praktikum pada Materi Titrasi Asam Basa. Jurnal Pendidikan dan Pembelajaran Kimia. 4(1), 83-94.

Kusaeri \& Suprananto. (2012). Pengukuran dan Penilaian Pendidikan. Graha Ilmu. Yogyakarta.

Oktriawan, T., Fadiawati, N, \& Rosilawati, I. (2015). Pengembangan Instrumen Asesmen Kinerja pada Praktikum Pengaruh Luas Permukaan Bidang Sentuh terhadap Laju Reaksi. Jurnal Pendidikan dan Pembelajaran Kimia. 4(2), 593-604.

Permendikbud No.65 Tahun 2013 tentang Standar Proses. Kemendikbud. Jakarta.

Permendikbud No.104 tentang Pedoman Penilaian Hasil Belajar oleh Pendidik. Kemendikbud. Jakarta.

Permendikbud No 59 tentang Kurikulum 2013 SMA/MA. Kemendikbud. Jakarta.

Stiggins, R. J. (1994). Student Centered Classroom Assesment. New York: Merrill.

Sudjana. (2005). Metode Statistika. Tarsito. Bandung.

Sudrajat, A., Permanasari, A., Zainul, A., \& Buchari. (2011). Pengembangan Rubrik Asesmen Kinerja untuk Mengukur Kompetensi Mahasiswa Melakukan Praktikum Kimia Analisis Volumetri. Jurnal Chemica, 12(1), 1-8.

Sukmadinata, N. S. (2011). Metodologi Penelitian Pendidikan. Remaja Rosdakarya. Bandung.

Susila, I. K. (2012). Pengembangan Instrumen Penilaian Unjuk Kerja (Performance Assesment) Laboratorium pada Mata Pelajaran Fisika Sesuai Kurikulum Tingkat Satuan Pendidikan SMA Kelas X Di Kabupaten Gianyar.Jurnal Penelitian dan Evaluasi Pendidikan, 2(2), 5-7.

Wulan, A. R. (2007). Penggunaan Asesmen Alternatif pada Pembelajaran Biologi. Seminar Nasional Biologi: Perkembangan Biologi untuk Menunjang Profesionalisme. Mei. 381-383.

Wulan, A. R. (2008). Skenario Baru bagi Implementasi Asesmen Kinerja pada Pembelajaran Sains di Indonesia. Jurnal Pendidikan. 29(3), 1-11.

Wulan, A. R. (2013). Penilaian Kinerja Portofolio Pada Pembelajaran Biologi. Artikel Pendidikan Biologi.1-16. 